\title{
Under Armour's Lawsuit Against Nike: Worth Breaking A Sweat?
}

Suresh Singh, Northeastern Illinois University, USA

\begin{abstract}
On February 12 of 2013, Under Armour launched I WILL ${ }^{\mathrm{TM}}$, its biggest ever global advertising campaign. Only nine days later, the company filed a lawsuit accusing Nike of illegally using variations of the I WILL TM trademark. This case study analyzes Nike's move and Under Armour's countermove. The case is well suited for initiating a broader discussion of competitive dynamics, especially of unconventional "hardball" and "curveball" strategies.
\end{abstract}

Keywords: Competitive Dynamics; Hardball Strategies; Curveball Strategies; Nike; Under Armour

\section{INTRODUCTION}

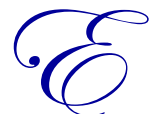

very day millions of athletes practice and compete wearing Under Armour (UA) or Nike clothes, shoes, equipment and accessories. However, it is not every day that these two companies dress up for a public fight in a courtroom. On February 21 of 2013, merely nine days after launching its global marketing campaign I WILL ${ }^{\text {TM }}$ (UA press release, 2013), UA filed a lawsuit against Nike, alleging trademark infringement (Case 1:13-cv-00571-ELH, 2013). In the lawsuit, UA claimed that its rights in the I WILL ${ }^{\text {TM }}$ mark go back to at least 1998 and complained that Nike had misappropriated the trademark by launching an advertising campaign in late 2012 deliberately built around the "I will" phrase (Exhibit 1). UA alleged that Nike's action was likely to "cause confusion, mistake, and deception as to the source or origin" of Nike and/or its products and, further, that it is likely to "falsely suggest a sponsorship, connection, or association" of Nike with UA.
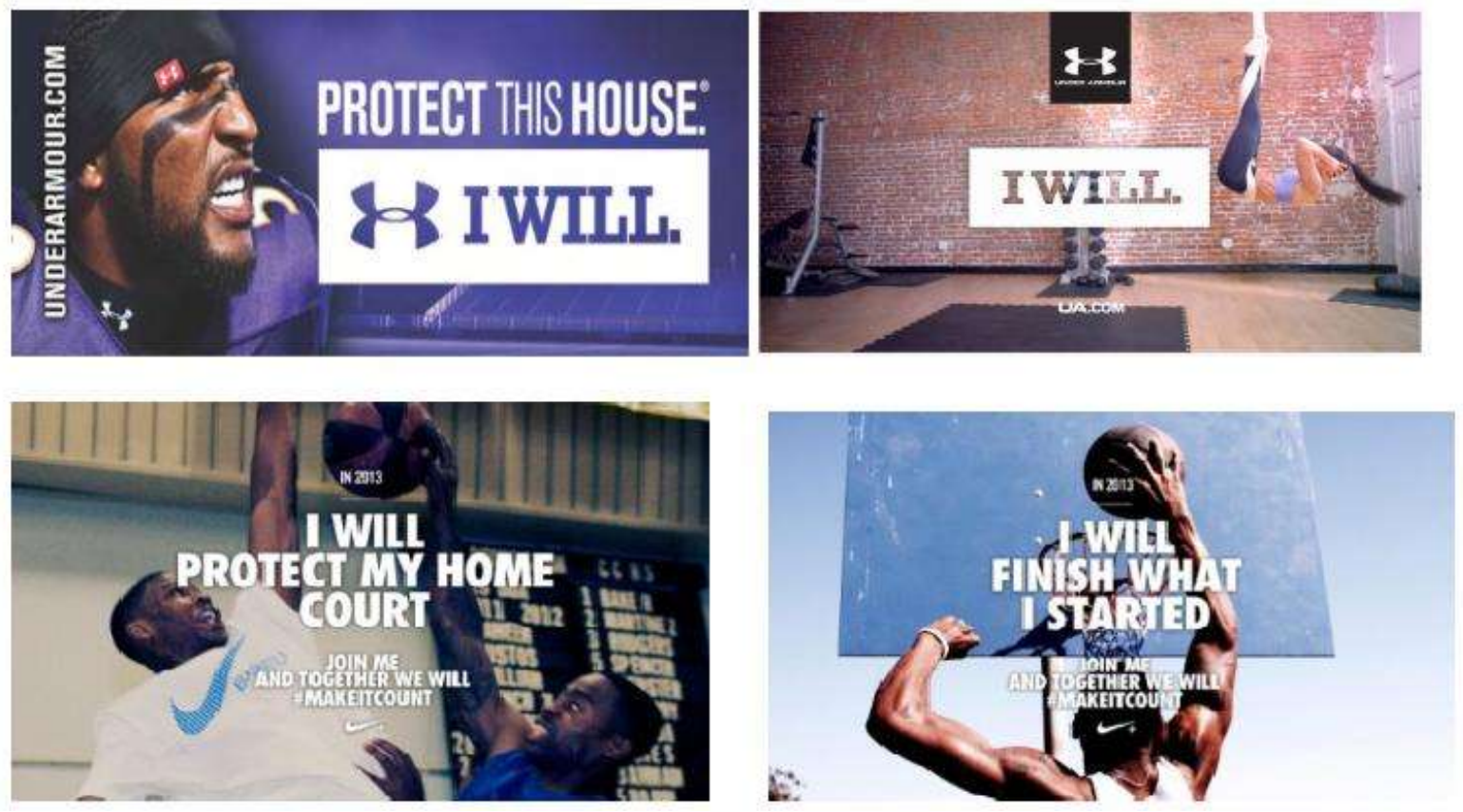

Exhibit 1: Under Armour and Nike's Use of "I Will" in Advertisements Source: Under Armour Lawsuit against Nike, February 21, 2013 
Nike responded by denying any wrongdoing. The company claimed, in its response to the lawsuit (Case 1:13-cv-00571-ELH, 2013), that it had used the noun-verb combination 'I will' well before UA purchased U.S. Trademark Registration No. 2,409,096 for 'I will' from Wells Investments, a US-based financial consulting firm. It noted that even after the sale of the trademark registration, Wells Investments retained the rights to the mark and continued its use for commercial purposes. Nike further claimed that others have also used the 'I Will' mark, including those who deal in athletics products. Accordingly, Nike described UA's claims in 'I Will' as "neither longstanding nor exclusive". Nike also claimed that before UA bought the trademark registration, Wells Investments had already abandoned rights to the mark 'I Will' for several articles of clothing, including blouses, pants, shorts, skirts, skorts, sweaters, vests, jeans, jerseys, sweatpants, sweat suits, jumpers, jackets, coats, beachwear, gloves, shoes, boots and slippers, socks, sports uniforms, cloth patches, arm bands, headbands, wristbands, and sweatbands. It further stated that in September 2012, UA filed a voluntary amendment under Section 7 of the Trademark Act in which it expressly deleted the aforementioned goods from the trademark Registration No. 2,409,096. Nike concluded that UA's alleged trademark rights in 'I will' are "weak, narrow, and exist in a crowded field of competing trademark uses and ordinary, plain-English uses". Nike emphasized that its own actions have been "innocent and not willful".

UA wasn't ready to back down easily. Company spokesman, Tai Foster, responded to Nike's response by saying, "We prefer to battle our competitors in the marketplace, but we must defend our brand when necessary and remain committed to vigorously protecting our 'I Will' trademark." (Symington, 2013a). The lawsuit was pending at the time of writing and it is anybody's guess what the verdict will be. This battle will end sooner or later, but the war between the two rivals is likely to simmer for a long time.

\section{NATURE OF COMPETITION BETWEEN NIKE AND UNDER ARMOUR}

The rivalry between Nike and UA is not new. In 2003, it was Nike that sued UA for infringement of the DRI-FIT trademark (Rovell, 2003). That lawsuit was later dismissed (Korman \& Wells, 2013), but the enmity between the two rivals has only intensified, as faster growing UA (Figure 1) entered the footwear segment in 2006 (UA annual reports) and challenged Nike's primary source of revenue (Nike annual reports). UA's push to make its presence felt in the international market (UA annual reports) has only added fuel to the fire.

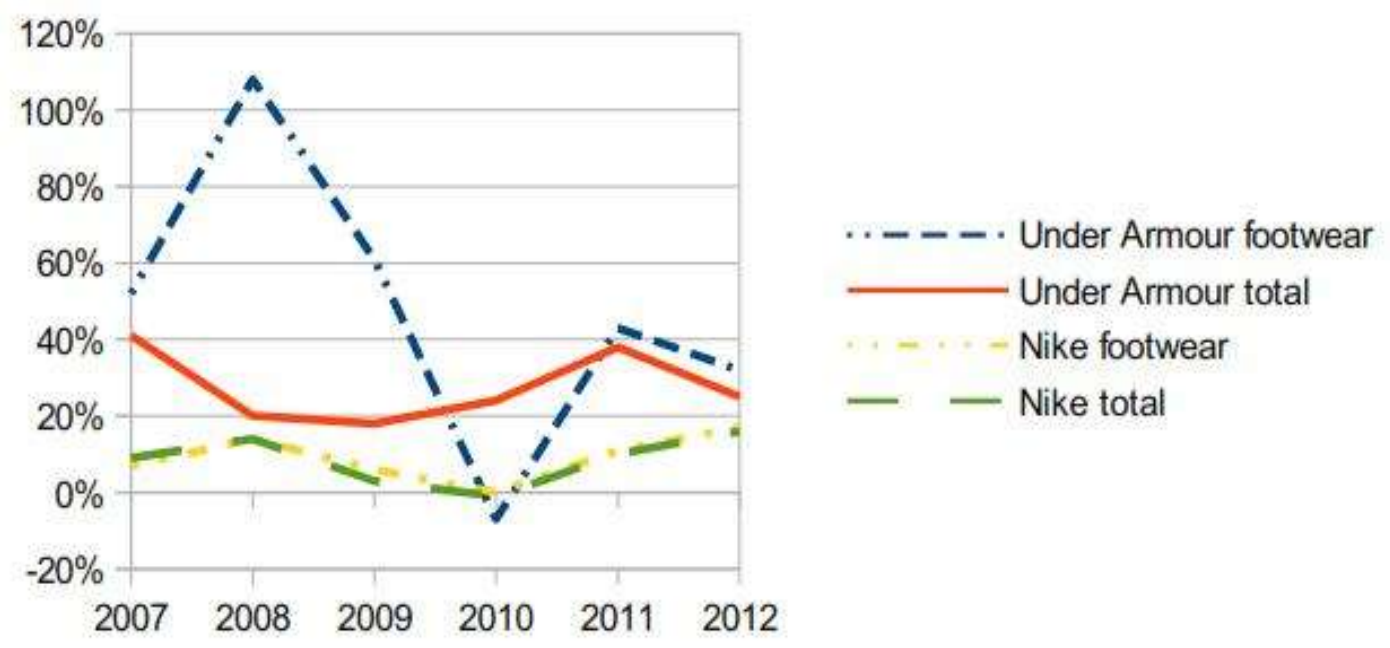

Figure 1: Revenue Growth, Under Armour Vs. Nike, 2007-2012 Source: Company Annual Reports

Bill Bowerman and Phil Knight (Nike website, 2013) founded Nike in 1964 as a distributor of athletic shoes. UA was created 32 years later as a manufacturer of performance apparel by Kevin Plank (Under Armour website, 2013). Even at the end of fiscal year 2012, footwear represented more than half of Nike's sales, while apparel constituted about three-fourths of UA's net revenue (Figure 2). However, in the seven years since its entry 
into the footwear category in 2006, UA's revenue from footwear grew nine-fold compared to a four-fold increase in its overall revenue (UA annual reports). The rapid growth of UA, especially in the footwear business, is increasingly threatening Nike. To make matters worse, Under Armour has not only entered all the major markets of the world but is also determined to grow its international business significantly in the years to come (UA annual reports). As a consequence, there is hardly any product or geographical segment in Nike's portfolio that is not under attack from UA.

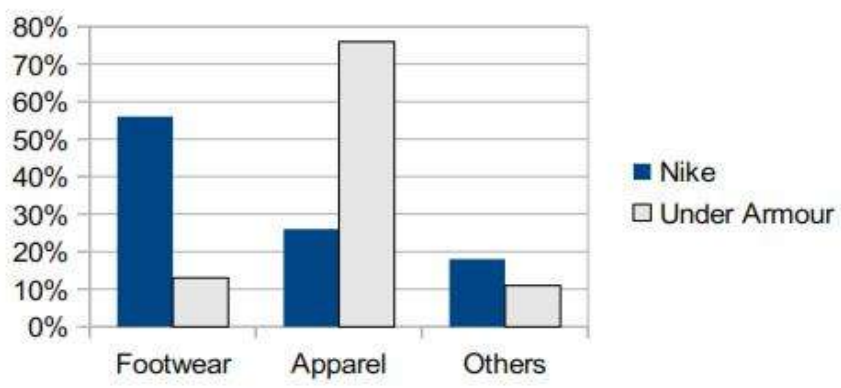

Figure 2: Revenue Breakdown by Product Categories, Nike Vs. Under Armour, 2012 Source: Company Annual Reports

The transformation of UA from a mere underdog to a worthy challenger to Nike - a giant of the industry - is praiseworthy, but it will be foolhardy for UA to underestimate its much bigger rival (Figure 3). At the end of fiscal 2012, Nike's total revenue was 13 times, and net income 17 times, that of UA. Further, Nike's cash and short term investments were about 11 times that of UA, giving Nike a considerably bigger war chest. Although UA has closed the gap in recent years, Nike clearly has the advantage of size. It is possible that Nike left UA alone, until now, precisely because UA wasn't big enough to be a serious threat. However, UA's rise and direct challenges to Nike's core business segments have undoubtedly put UA in the cross hairs of Nike. If the 2003 lawsuit filed by Nike against UA was a warning shot, then Nike's current move is proof enough that Nike is not in the mood to cede territory just yet.

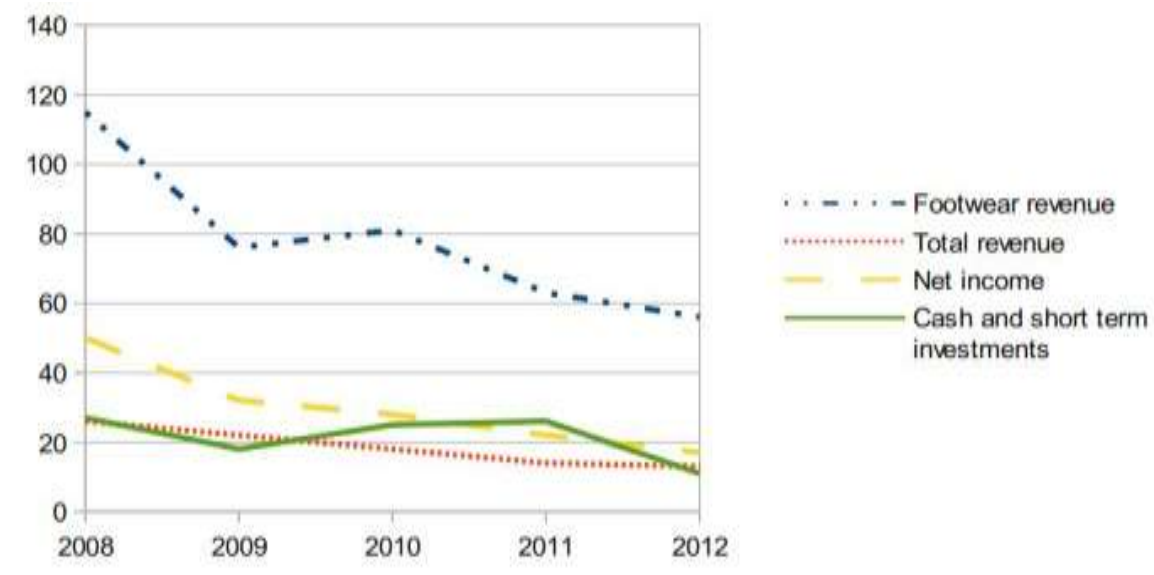

Figure 3: Size Comparison, Nike's Figures as Multiples of Under Armour's Source: Company Annual Reports

\section{DISCUSSION QUESTIONS}

1. Is Nike's advertising campaign "innocent and not willful"? What hidden strategic intentions may be lurking behind Nike's move?

2. Was a lawsuit the best countermove available to UA, given that Nike had considerably more resources (and experience) to indulge in such legal maneuvers? More broadly, was it prudent for UA to enter and thereby challenge Nike in later core business segments?

3. Which company is more likely to benefit from the current legal battle? 


\section{ANSWERS TO THE DISCUSSION QUESTIONS}

A preview of answers is presented below. Detailed answers will be made available by the author on request. Faculty at academic institutions will receive complimentary copies if they provide their official email addresses.

It is hard to believe that Nike did not know about UA or its I WILLTM advertising campaign (Korman, 2013). The 2003 lawsuit filed by Nike against UA belies Nike's claim of innocence by showing not only Nike's awareness of UA, but also its keen alertness about trademark issues. What Nike is doing here is using a combination of hardball and curveball strategies (Stalk \& Lachenauer, 2004; Stalk, 2006). The lawsuit is merely a means to a larger end, and that is to thwart a challenger who is increasingly looking dangerous. Nike aims to distract and delay (Symington, 2013b) its rival and is least bothered by the outcome of the lawsuit (Korman, 2013). By responding vigorously to Nike's move, UA may have fallen into Nike's trap. UA cannot match Nike in terms of resources and a head-to-head battle is probably going to benefit Nike more than UA. In its zeal to challenge Nike, UA has entered the footwear segment and international markets in rapid succession. Although UA has proven its mettle as a worthy challenger, biting more than it can chew may prove to be a recipe for disaster.

\section{AUTHOR INFORMATION}

Suresh Singh received his Ph.D. in business administration from the Ohio State University in 2011. He is currently an assistant professor of strategic management at the Northeastern Illinois University, Chicago, USA. His research interests are strategic management and international business. Suresh has been an assistant consultant with Tata Consultancy Services, where he worked for six years. E-mail: $\underline{\text { S-Singh1@ @ neiu.edu }}$

\section{REFERENCES}

1. Case 1:13-cv-00571-ELH. (2013). Under Armour, Inc. v. Nike, Inc. District Court of Maryland, USA.

2. Korman, C. (2013, February 22). Lawsuit called another 'skirmish' as Under Armour takes aim at Nike. Retrieved from http://articles.baltimoresun.com/2013-02-22/business/bs-bz-under-armour-nike20130222 1 nike-phil-knight-brand

3. Korman, C. \& Wells, C. (2013). Under Armour sues Nike for infringing on 'I Will' trademark. Retrieved from http://articles.baltimoresun.com/2013-02-21/news/bs-bz-under-armour-sues-nike-20130221_1_niketrademark-baltimore-sports-apparel

4. Nike website (2013, July 11). Retrieved from http://nikeinc.com/pages/history-heritage

5. Nike annual reports. Retrieved from http://investors.nikeinc.com/Investors/Financial-Reports-andFilings/Annual-Reports/default.aspx

6. $\quad$ Rovell, D. (2003). Nike sweating trademark infringement. Retreived from http://espn.go.com/sportsbusiness/news/2003/0403/1533473.html

7. Stalk, G., \& Lachenauer, R. (2004). Hard Ball: Five Killer Strategies for Trouncing the Competition. Harvard Business Review. 82(4): 62-71.

8. Stalk, G. (2006). Curveball strategies to fool the competition. Harvard Business Review, 84(9): 114-22.

9. Symington, S. (2013a, May 04). Nike Strikes Back at Under Armour: Is "I Will" Famous? Retrieved from http://www.fool.com/investing/general/2013/05/04/nike-strikes-back-is-i-will-famous.aspx

10. Symington, S. (2013b, Feb 22). Under Armour Sues Nike: Is it Worth it? Retrieved from http://www.fool.com/investing/general/2013/02/22/under-armour-sues-nike-is-it-worth-it.aspx

11. Under Armour annual reports. Retreived from http://investor.underarmour.com/annuals.cfm

12. Under Armour press release. 2013. Under Armour Launches I WILL ${ }^{\mathrm{TM}}$, its Biggest Ever Global Marketing Campaign. Retrieved from http://investor.underarmour.com/releasedetail.cfm?ReleaseID=739814

13. Under Armour website. (2013, July 11). Retrieved from http://investor.underarmour.com/company/about.cfm 